\title{
MODEL HIPOTESIS PENERAPAN SATUAN KREDIT KOMPETENSI (SKK) PADA PROGRAM PENDIDIKAN KESETARAAN
}

\author{
Supriyono*
}

\begin{abstract}
Based on the regulation of Minister of National Education, No. 14 of 2007 about the standard content for the program of $A, B$, and $C$ packages, the attainment of learning achievement competence, named as the unit of competence credit (SKK) has been regulated. The system of SKK at equivalency is education in different from semester credit system (SKS) at higher education. This article discusses SKK introducing an implementation model by distributing the learning loads on each competence unit or sub unit into SKK unit. SKK system will enable to implement various flexibility competence and excellence competence of nonformal education. Besides, several learning models in nonformal education can be integrated in one interconnected system, i.e. SKK and national examination of equivalency education.
\end{abstract}

Keywords: equivalency education, competence credit unit, examination for equivalency education.

\section{PENDAHULUAN}

Pada tahun 1994 pemerintah mulai melaksanakan program wajib belajar pendidikan dasar sembilan tahun, jalur Pendidikan Luar Sekolah (PLS) meluncurkan Program Paket A Setara SD dan Program Paket B Setara SMP. Kedua program itu mendapat sambutan yang baik dari masyarakat. Mulai tahun 2000 masyarakat yang telah menyelesaikan Paket B Setara SLTP kembali diberikan peluang belajar lanjutan pada rintisan Program Paket C. Pada tahun 2001 Paket $C$ pertama kali dan ujian nasional dilakukan, yang kemudian pengakuan pengesahannya pada tahun 2004 (Dit. Pendidikan Kesetaraan, Ditjen PLS, 2006).

Desain awal program paket disediakan bagi anak atau orang karena berbagai situasi, kondisi, dan alasan tidak bisa menempuh pendidikan melalui jalur sekolah. Cikal bakal dari program paket adalah program Pemberantasan Buta Huruf (PBH) yang kemudian dikembangkan menjadi Program Paket A dengan buku paket yang berjudul Aksara dan Angka pada tahun 1980an. Seiring dengan perkembangan kebutuhan, melalui Keputusan Mendiknas Nomor 0132/U/1994, Program Paket A dan ditambah Program Paket B ditingkatkan peran dan fungsinya sebagai jalur alternatif dalam penuntasan wajib belajar sembilan tahun. Dalam status baru ini derajat kelulusan program paket diakui setara dengan lulusan sekolah SD atau MI dan SMP atau MTs. Akhirnya, program ini disebut sebagai Program

* Dosen PLS Universitas Negeri Malang
Pendidikan Kesetaraan. Pada tingkat SMTA diluncurkan Program Paket $C$ dengan payung hukum berupa Keputusan Mendiknas Nomor 132/U/2004.

Peran Program Paket semakin penting dan strategis ketika Direktur Jendral Pendidikan Dasar dan Menengah Departemen Pendidikan Nasional menerbitkan surat edaran No. 3633/C/MN/2002 tanggal 27 Mei 2002 Tentang Penghapusan Program Ujian Persamaan (upers). Kebijakan ini dikuatkan oleh Keputusan Mendiknas Nomor 086/U/2003 tentang Penghapusan Ujian Persamaan. Dengan ditiadakannya jalur upers, program kejar paket merupakan satusatunya sarana bagi masyarakat yang tidak dapat menempuh pendidikan melalui jalur pendidikan formal dengan alasan tertentu. Dengan demikian, program paket mencapai formatnya yang lebih sempurna dengan sebutan sebagai Program Pendidikan Kesetaraan. Bahkan seiring dengan perubahan organisasi di lingkungan Departemen Pendidikan Nasional (Depdiknas), pada tahun 2005 telah dibentuk direktorat yang secara khusus menangani pendidikan kesetaraan, yaitu Direktorat Pendidikan Kesetaraan.

Direktorat Pendidikan Kesetaraan Ditjen PLS Depdiknas (2006) melaporkan jumlah peserta didik Program Paket semakin bertambah ditinjau dari jumlah peserta yang mengikuti Ujian Nasional Pendidikan Kesetaraan (UNPK). Berikut adalah gambaran peningkatan jumlah peserta UNPK untuk Program Paket C. 


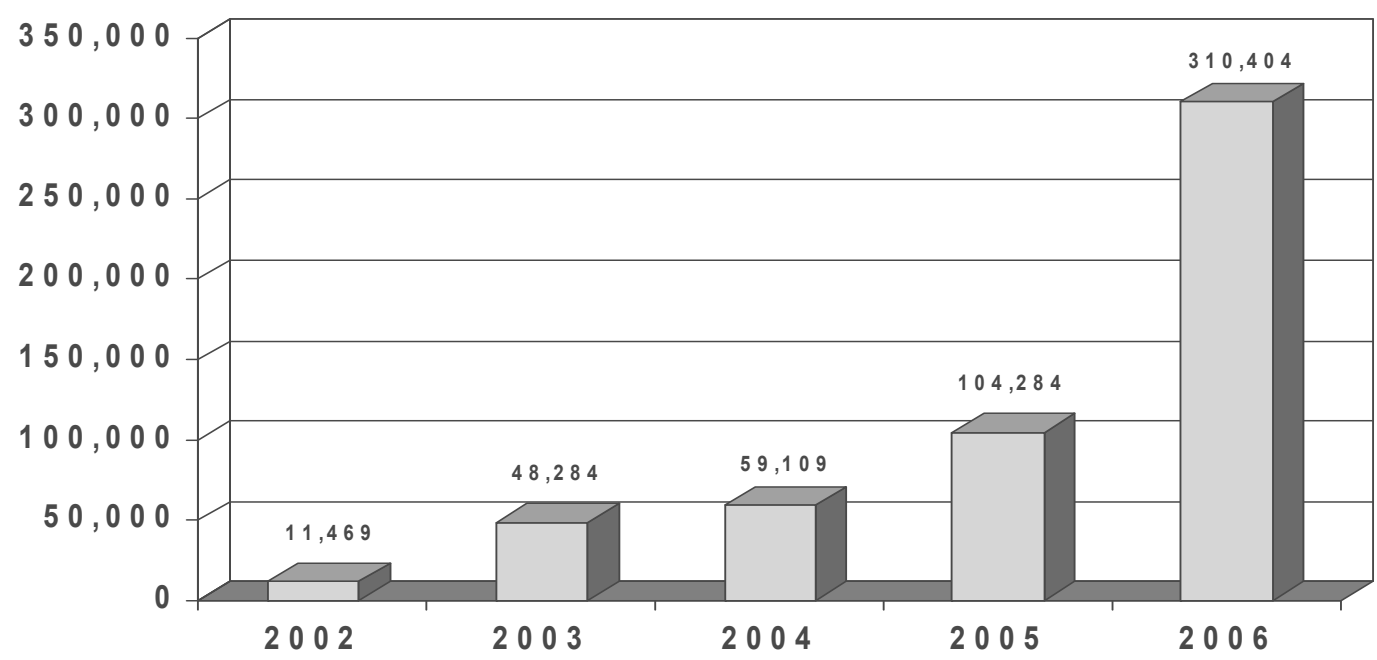

Gambar grafik jumlah peserta program paket C tahun 2002-2006

(Sumber: Dit Kesetaraan, Ditjen PLS Depdiknas, 2006)

Berdasarkan grafik di atas, jumlah peserta didik Program Paket $\mathrm{C}$ mengalami peningkatan yang cukup signifikan. Peningkatan jumlah peserta UNPK menjadi lebih tinggi lagi dengan munculnya kebijakan ditiadakannya ujian ulangan pada UN sekolah formal pada tahun 2006.
Sementara itu, data lain yang dicatat oleh Direktorat Pendidikan Kesetaraan Ditjen PLS Depdiknas (Yulaelawati, 2005) menunjukkan data perkembangan peserta UNPK dari tahun 2002 sampai 2005 adalah seperti tertera pada Tabel 1 dan Tabel 2 berikut.

Tabel 1. Jumlah Peserta UNPK dari Tahun 2002-2005

\begin{tabular}{|c|c|c|c|c|c|c|c|c|c|c|c|c|}
\hline \multirow{3}{*}{$\begin{array}{l}\text { PRO- } \\
\text { GRAM }\end{array}$} & \multicolumn{12}{|c|}{ TAHUN } \\
\hline & \multicolumn{3}{|c|}{2002} & \multicolumn{3}{|c|}{2003} & \multicolumn{3}{|c|}{2004} & \multicolumn{3}{|c|}{2005} \\
\hline & D & $\mathbf{P}$ & $\mathrm{L} / \%$ & D & $\mathbf{P}$ & L / \% & D & $\mathbf{P}$ & L/ $\%$ & D & $\mathbf{P}$ & $L / \%$ \\
\hline Paket A & 7.705 & 6.487 & $\begin{array}{l}6.126 \\
94,44\end{array}$ & 12.313 & 9.782 & $\begin{array}{l}3.251 \\
33,24^{* *}\end{array}$ & 26.105 & 19.955 & $\begin{array}{l}16.191 \\
81,14\end{array}$ & 23.066 & 17.370 & $\begin{array}{l}14.530 \\
83,65\end{array}$ \\
\hline Paket B & 44.434 & 37.877 & $\begin{array}{l}34.922 \\
92,20\end{array}$ & 33.990 & 27.859 & $\begin{array}{l}23.961 \\
86,01\end{array}$ & 108.150 & 88.521 & $\begin{array}{l}65.138 \\
73,58\end{array}$ & 102.639 & 85.948 & $\begin{array}{l}71.667 \\
83,38\end{array}$ \\
\hline Paket C & 22.057 & 19.347 & $\begin{array}{l}11.469 \\
59,28^{*} \\
*\end{array}$ & 71.596 & 62.580 & $\begin{array}{l}48.284 \\
77,16\end{array}$ & 102.221 & 84.593 & $\begin{array}{l}59.109 \\
6,87\end{array}$ & 68.297 & 63.569 & $\begin{array}{l}41.384 \\
65,10\end{array}$ \\
\hline
\end{tabular}

Keterangan: $D=$ pendaftar; $P=$ peserta; $L=$ lulus $\left.{ }^{* *}\right)=$ Data tidak lengkap.

Tabel 2. Jumlah Peserta UNPK Periode II Tahun 2006*)

\begin{tabular}{|l|l|l|l|}
\hline \hline PROGRAM & PESERTA & LULUS & PROPORSI \\
\hline \hline PAKET A & 9.178 & 8.068 & $87,91 \%$ \\
\hline PAKET B & 210.169 & 194.674 & $92,63 \%$ \\
\hline PAKET C IPS & 384.698 & 332.149 & $86,34 \%$ \\
\hline PAKET C IPA & 23.682 & 17.008 & $71,82 \%$ \\
\hline
\end{tabular}

Keterangan: *) Data yang tersedia hanya untuk periode II yang dilakukan pada tanggal 28 Agustus-2 September 2006. 
Tabel 1 dan tabel 2 tersebut menunjukkan peningkatan jumlah peserta UNPK serta persentase kelulusannya yang bergerak antara $65 \%$ sampai dengan $93 \%$. Hal yang biasa terjadi pada pendidikan kesetaraan adalah tingkat kelulusan UN yang rendah dibanding tingkat kelulusan UN pendidikan formal. Dalam hal inilah terbukti adanya kelebihan dan "kealamiahan" pendidikan kesetaraan, meskipun tingkat kelulusannya kurang dari $90 \%$ tidak menimbulkan gejolak masyarakat. Semua berjalan secara alamiah, tidak lulus pada UNPK adalah hal biasa dan berarti warga belajar perlu belajar lagi lebih baik.

Isu akreditasi dan sertifikasi pendidikan kesetaraan menjadi lebih populer ketika sensasi sekolahrumah (homeschooling) menjadi sebuah isu yang sangat hangat di dunia pendidikan Indonesia pada awal tahun 2006/2007. Isu itu terutama terjadi ketika pemikiran dan praktik sekolahrumah diakomodasi oleh jajaran Direktorat Pendidikan Kesetaraan Direktorat Jenderal Pendidikan Luar Sekolah atau Pendidikan Nonformal dan Informal Departemen Pendidikan Nasional (Dit Pendidikan Kesetaraan Ditjen PLS atau PNFI Depdiknas, 2007). Cara mengakomodasinya adalah dengan mengembangkan prosedur operasi standar pengakuan (akreditasi) pengalaman belajar yang diperoleh melalui sekolah rumah sebagai pengalaman belajar pada Program Pendidikan Kesetaraan. Melalui mekanisme recognition of prior learning, pengalaman belajar yang didapat (calon) peserta didik diakui (diakreditasi) dengan penghargaan tertentu. Berdasarkan pengakuan itu, beban belajar mereka terkurangi karena telah memiliki pengalaman belajar pendahuluan.

Di tengah meningkatnya animo masyarakat untuk mengikuti Program Pendidikan Kesetaraan maka menjadi sebuah kebutuhan untuk membangun sistem pengelolaan, pembelajaran dan sertifikasi, serta akreditasi yang baik, kredibel, dan berkeadilan. Dengan terbangunnya sistem pengelolaan, pembelajaran dan sertifikasi, serta akreditasi yang baik, kredibel, dan berkeadilan itu maka banyak manfaat yang bisa didapatkan. Terciptanya masyarakat belajar (learning community) akan lebih mudah diwujudkan bila sistem pembelajaran masyarakat (melalui jalur nonformal dan informal) telah tertata dengan baik. Warga masyarakat akan senang belajar karena efek sipil (civil effect) akan diperoleh dengan mengikuti Program Paket $C$ sama eligibilitasnya dengan lulusan pendidikan jalur sekolah (Yulaelawati, 2005). Pemerintah dan negara akan lebih stabil karena terdapat sistem pembelajaran yang baik dan dapat melindungi warga negara dari praktik-praktik pendidikan yang sesat (mal praktik pendidikan). Salah satu pemecahan yang bisa diharapkan mampu menjembatani peningkatan animo, kebutuhan belajar lanjutan, dan kelemahan penyelenggaraan pendidikan kesetaraan adalah penerapan sistem Satuan Kredit Kompetensi (SKK). Rencana pemberlakuan sistem SKK pada pendidikan kesetaraan atau yang biasa disebut sebagai Program Paket A, Paket B, dan Paket $C$ apakah dapat menjadi solusi bagi pembangunan sistem pembelajaran, akreditasi, dan sertifikasi pada Program Pendidikan Kesetaraan ini.

\section{PEMBAHASAN}

\section{Payung Hukum SKK}

Penerapan SKK pada pendidikan kesetaraan itu merupakan implementasi dari Peraturan Pemerintah (PP) No. 19 Tahun 2005 Tentang Standar Nasional Pendidikan, khususnya pada bagian ketiga tentang beban belajar sebagaimana tercantum pada pasal 11 . Walaupun dalam PP 19/2005 tersebut istilah yang digunakan adalah Satuan Kredit Semester (SKS) dan ditujukan untuk program pendidikan formal dari tingkat SMP dan SMA. Pada pasal 11 ayat (3) tertulis beban belajar minimal dan maksimal bagi satuan pendidikan yang menerapkan sistem SKS ditetapkan dengan Peraturan Menteri (Permen) berdasarkan usul Badan Standar Nasional Pendidikan (BSNP). BSNP adalah badan mandiri dan independent yang bertugas mengembangkan, memantau pelaksanaan, dan mengevaluasi standar nasional pendidikan.

Perlu dibedakan istilah "SKK" (menggunakan huruf kapital) dengan "skk" (menggunakan huruf kecil). SKK, dengan huruf besar menunjuk pada sistem sedangkan skk dengan huruf kecil menunjuk pada rincian satuan harga atau nilai. Pembedaan istilah ini analog dengan yang berlaku di perguruan tinggi (UM, 2007). Pada uraian selanjutnya penggunaan SKK dan skk akan saling dipertukarkan.

\section{Standar Isi}

Pendidikan kesetaraan akan mampu menjamin pemerataan kesempatan pendidikan, peningkatan mutu dan relevansi, serta efisiensi manajemen pendidikan. Pemerataan kesempatan pendidikan diwujudkan dalam program wajib belajar sembilan tahun. Peningkatan mutu pendidikan diarahkan untuk meningkatkan kualitas manusia Indonesia seutuhnya melalui olahhati, olahpikir, olahrasa, olahraga, dan olahkarya agar memberikan peluang kepada warga belajar untuk belajar sesuai dengan gaya belajar dan tingkat kesanggupan 
masing-masing. Dengan sistem SKK, ada kesempatan lebih luas kepada warga belajar yang cerdas dan punya sumber daya untuk menyelesaikan pendidikan kesetaraan lebih cepat daripada bila ia harus mengikuti sistem reguler melalui pembelajaran semester dan klasikal sebagaimana yang biasa terjadi.

\section{Salah Satu Model Implementasi SKK}

Secara konseptual model SKK dapat menggunakan kombinasi preseden model SKS dan sks di perguruan tinggi dan pada sekolah, model syarat kecakapan umum, dan syarat kecakapan khusus pada Gerakan Pramuka, serta model Iqro' untuk pembelajaran huruf Arab. Dengan demikian, secara konseptual model SKK untuk pendidikan kesetaraan merupakan turunan (derivasi) dari sistem atau sks di perguruan tinggi, sistem syarat kecakapan umum dan syarat kecakapan khusus pada Gerakan Pramuka, serta model Iqro' pada pembelajaran baca tulis huruf Arab.

Pada sistem sks di perguruan tinggi untuk memperoleh seperangkat kompetensi, mahasiswa ditamsilkan memprogram atau mengambil sejumlah satuan kredit untuk setiap satuan semester. Untuk melunasi kredit itu ia harus mengerjakan tiga kegiatan belajar secara terintegratif, yakni kuliah tatap muka, mengerjakan tugas terstruktur, dan mengerjakan tugas mandiri. Apabila ia mampu memenuhi persyaratan administratif dan tugas perkuliahan tersebut sebagaimana yang dipersyaratkan maka dosen pembina mata kuliah di bawah panduan pedoman akademik universitas akan menyatakan mahasiswa yang bersangkutan lulus dan memperoleh sejumlah bobot kredit sesuai yang tertera pada kurikulum program studi. Seorang mahasiswa dinyatakan lulus sebuah jenjang pendidikan tententu apabila telah mampu membukukan (lulus) semua sks yang dipersyaratkan.

Dalam perkuliahan dengan sistem sks di perguruan tinggi, untuk kuliah jenis mata kuliah teori, kuliah tatap muka (contact-hours) hanya menempati kurang dari sepertiga dari jumlah jam belajar yang harus dijalani oleh mahasiswa untuk diakui sebagai bernilai satu sks. Lebih jelasnya, suatu mata kuliah teori akan bernilai satu sks, jika mata kuliah tersebut diselenggarakan tiap minggu sebanyak 1 X 50 menit tatap muka, ditambah $1 \times 60$ menit pengerjaan tugas terstruktur, dan ditambah lagi dengan 1 X 60 menit pengerjaan tugas mandiri dalam satu semester. Satu semester kurang lebih sebanyak 18 minggu. Tuntutan jumlah jam atau menit belajar tersebut akan lebih tinggi untuk jenis mata kuliah praktikum dan mata kuliah kerja lapangan. Untuk mata kuliah praktikum 2 X 50 menit, ditambah $1 \times 60$ menit. Untuk mata kuliah lapangan 4 X 50 menit, ditambah 1 X 60 menit, ditambah 1 X 60 menit (Konsorsium Ilmu Pendidikan, 1980).

Model syarat kecakapan umum dan syarat kecakapan khusus pada Gerakan Pramuka digunakan sebagai instrumen pengelolaan pengakuan kecakapan anggota Pramuka. Syarat kecakapan umum digunakan untuk mengukur dan mengakui kemampuan anggota pada kompetensi umum kepramukaan, mulai dari komitmennya terhadap organisasi, kerajinannya mengikuti latihan-latihan, dan penguasaannya terhadap kompetensi umum kepramukaan. Adapun syarat kecakapan khusus digunakan untuk mengukur dan mengakui kemampuan anggota pada kompetensi khusus yang disebut kemampuan kesakaan. Dalam gerakan Pramuka dikenal adanya enam jenis kegiatan kesakaan, yakni pembelajaran ketrampilan khusus yang bersifat vokasional agar anggota pramuka memiliki kemampuan bekerja mencari nafkah atau menekuni hobi konstruktif yang bisa membimbingnya menjadi manusia yang berguna. Enam jenis saka itu adalah sebagai berikut.

1. Saka Taruna Bumi untuk ajang belajar keterampilan pertanian.

2. Saka Bahari untuk ajang belajar keterampilan kelautan.

3. Saka Kencana untuk yang ingin belajar dan berhobi mengkampanyekan program keluarga berencana.

4. Saka Bhakti Husada untuk ajang belajar jasa kesehatan.

5. Saka Wana Bhakti untuk ajang pembelajaran ketrampilan dan hobi kehutanan.

6. Saka Dirgantara untuk anggota yang berhobi kedirgantaraan.

Daftar satuan syarat kecakapan umum dan syarat kecakapan khusus tertulis dalam sebuah buku saku yang harus dimiliki oleh seorang anggota pramuka. Sepanjang latihan, seorang anggota pramuka belajar berbagai kecakapan hidup sesuai dengan jenjang usia dan kemampuan yang disediakan untuknya, sesuai dengan lingkungan alam-sosial yang bersangkutan. Apabila ia merasa telah menguasai satu atau lebih satuan syarat kecakapan umum atau syarat kecakapan khusus maka ia mengajukan diri untuk diuji oleh pembinanya. Setelah pembina melakukan pengukuran (asesment) terhadap anggota yang bersangkutan dan merasa puas atas performance anggota sesuai dengan peraturan dan berlandaskan kode etik dan profesionalisme pembina pramuka maka pembina tersebut memberikan paraf yang berarti memiliki daya saing dalam menghadapi tantangan global. Peningkatan relevansi pendidikan dimaksudkan 
untuk menghasilkan lulusan yang sesuai dengan tuntutan kebutuhan berbasis potensi sumber daya alam Indonesia. Peningkatan efisiensi manajemen pendidikan dilakukan melalui penerapan manajemen berbasis masyarakat dan otonomi perguruan tinggi serta pembaharuan pengelolaan pendidikan secara terencana, terarah, dan berkesinambungan.

Pendidikan kesetaraan adalah program pendidikan nonformal yang menyelenggarakan pendidikan umum setara SD atau MI, SMP atau MTs, dan SMA atau MA yang mencakup Program Paket $A$, Paket $B$, dan Paket $C$. Penghargaan terhadap hasil belajar pendidikan kesetaraan tersebut mengacu pada ketentuan pasal 26 ayat (6) Undang-undang Sisdiknas yang menyatakan: "Pendidikan nonformal dapat dihargai setara dengan hasil program pendidikan formal setelah melalui proses penilaian penyetaraan oleh lembaga yang ditunjuk oleh Pemerintah atau pemerintah daerah dengan mengacu pada standar nasional pendidikan".

Memenuhi tuntutan Undang-Undang (UU) No. 20 Tahun 2003 Tentang Sistem Pendidikan Nasional (sisdiknas) yang secara khusus dijabarkan ke dalam sejumlah peraturan, antara lain PP No. 19 Tahun 2005 Tentang Standar

Nasional Pendidikan, pendidikan kesetaraan dikembangkan pula menuju baku mutu yang terstandar. PP ini memberikan arahan tentang perlunya disusun dan dilaksanakan delapan standar nasional pendidikan, yaitu standar isi, proses, kompetensi lulusan, pendidik dan tenaga kependidikan, sarana dan prasarana, pengelolaan, pembiayaan, dan penilaian pendidikan.

Pada pendidikan kesetaraan telah dikembangkan standar isi sebagaimana dimaksud oleh PP No. 19 Tahun 2005. Standar isi secara keseluruhan mencakup lingkup materi dan tingkat kompetensi untuk mencapai standar kompetensi lulusan pada pendidikan kesetaraan yang terdiri atas sejumlah mata pelajaran yang sama dengan pendidikan formal untuk kepentingan ujian penyetaraan tingkat nasional dan sejumlah mata pelajaran yang menekankan pada penguasaan pengetahuan dan keterampilan fungsional serta pengembangan sikap dan kepribadian profesional. Seluruh ketentuan tentang standar isi pendidikan kesetaraan tersebut telah ditetapkan melalui Permendiknas No. 14 Tahun 2007. Standar isi ini dikembangkan oleh BSNP berdasarkan PP No. 19 Tahun 2005.
Salah satu hal yang dimuat dalam standar isi tersebut adalah digunakannya satuan kredit kompetensi (SKK) sebagai cara untuk menghargai penguasaan kompetensi atau ketuntasan belajar yang dicapai oleh para peserta didik pendidikan kesetaraan. Dalam hal ini SKK menjadi sebuah model resmi dalam penyelenggaraan pendidikan kesetaraan.

\section{Esensi SKK}

SKK pada Program Pendidikan Kesetaraan atau yang biasa disebut sebagai Program Paket $A$, Paket $B$, dan Paket $C$ dimaksudkan untuk menilai atau menghargai beban belajar yang telah dijalani dan diperoleh oleh peserta didik. Pada lampiran Permendiknas tersebut disebutkan, beban belajar Program Paket A, Paket B, dan Paket C dinyatakan dalam SKK yang menunjukkan bobot kompetensi yang harus dicapai oleh peserta didik dalam mengikuti program pembelajaran, baik melalui tatap muka, praktik keterampilan, dan atau kegiatan mandiri.

Pada penjelasan Permendiknas selanjutnya SKK merupakan penghargaan terhadap pencapaian kompetensi sebagai hasil belajar peserta didik dalam menguasai suatu mata pelajaran. SKK diperhitungkan untuk setiap mata pelajaran yang terdapat dalam struktur kurikulum. Pada sisi lain, penerapan sistem SKK itu merupakan implementasi isi dari PP No. 19 Tahun 2005 Tentang Standar Nasional Pendidikan, khususnya pada bagian ketiga tentang beban belajar, yaitu tercantum pada pasal 11. Walaupun dalam PP 19/2005 tersebut istilah yang digunakan adalah SKS (bukan SKK) dan ditujukan untuk program pendidikan formal dari tingkat SMP atau MTs atau SMPLB dan SLA (SMA atau MA atau SMLB atau SMK atau MAK). Pada pasal tersebut pada ayat (3) tertulis beban belajar minimal dan maksimal bagi satuan pendidikan yang menerapkan sistem SKS ditetapkan dengan Permen berdasarkan usul BSNP.

Memang masih terlalu dini untuk membicarakan hal-hal teknis operasional penerapan SKK pada Program Pendidikan Kesetaraan. Masih butuh pembahasan secara teoretis, konseptual dan kelayakterapannya di lapangan. Untuk itu, dibutuhkan banyak diskusi dan penelitian uji coba. Namun justru pada tahapan embrio ini penting untuk dilakukan diskusi secara intensif dan cerdas agar ketika diimplementasikan nanti telah ada arah yang agak jelas, jabaran rinci dan panduan operasional yang telah teruji. 
Pada tahun 2007 ini BSNP tengah merumuskan standar proses untuk penyelenggaraan pendidikan kesetaraan, setelah pada tahun 2006 berhasil merumuskan standar isi pendidikan kesetaraan dengan akte kelahiran berupa Permendiknas No. 14 Tahun 2007 seperti telah tersebut di muka.

Salah satu alasan utama rencana penerapan sistem SKK pada pendidikan kesetaraan adalah persetujuan pada buku syarat kecakapan umum atau syarat kecakapan khusus yang dimiliki anggota, sebagai bukti bahwa anggota itu telah cakap mengerjakan sebuah kompetensi. Demikian seterusnya sampai sejumlah kecakapan yang dipersyaratkan pada satu jenjang jabatan terpenuhi maka anggota pramuka itu boleh mengajukan ujian kenaikan tingkat. Anggota pramuka yang tidak pernah mengajukan ujian syarat kecakapan umum atau syarat kecakapan khusus maka yang bersangkutan tidak akan pernah mendapatkan brevet kecakapan tingkat tertentu.

Salah satu model metode pembelajaran yang cukup banyak digunakan dalam pengembangan kemampuan mengkaji agama Islam, khususnya dalam hal baca tulis huruf Arab adalah metode Iqro'. Dengan metode ini kemampuan membaca huruf Arab disusun secara berjenjang sebanyak enam tahapan yang disebut Iqro' satu sampai dengan Iqro' enam. Pada Iqro' satu adalah pelajaran yang paling sederhana berupa pelajaran pengenalan abjad huruf hijaiyah beserta harokat-nya. Seorang siswa harus terlebih dulu menguasai secara sempurna (mastery) kompetensi yang tertuang pada Iqro' satu sebelum beranjak ke pelajaran pada Iqro' dua. Keterangan tingkat penguasaan kompetensi itu dicatat dalam sebuah buku semacam buku rapor yang berisi tingkatan-tingkatan kompetensi baca tulis secara hierarki. Pihak yang berwenang menetapkan tingkat penguasaan itu adalah para pengajar, yakni para Ustaz atau Ustazah (tutor). Dengan demikian, setidaknya terdapat dua jenis dokumen yang dimiliki oleh setiap siswa sebagai komponen model Iqro', yaitu buku paket belajar Iqro' dan buku catatan laporan kemajuan belajar siswa.

Berdasarkan buku laporan tingkat penguasaan kemampuan baca tulis tersebut seorang siswa Taman Pendidikan Al Qur'an (TPA) dapat melanjutkan pelajaran baca tulisnya dimanapun ia bermukim. Bilamana suatu saat dia berpindah tempat tinggal, sepanjang ada lembaga penyedia layanan atau penyelenggara program Iqro' maka dia bisa meminta program belajar lanjutannya setelah terlebih dahulu menjalani tes penempatan. Apabila dia sempat putus belajar maka untuk memulai lagi program belajarnya, sang Ustaz akan melakukan tes penempatan untuk mengetahui pelajaran berikutnya harus dimulai lagi. Dengan metode Iqro' proses belajar dapat menerapkan sistem multientry and multiexit, yakni kapanpun bisa memulai belajar dan kapanpun bisa putus belajar dengan berbagai alasannya untuk suatu saat nanti melanjutkan lagi program belajar ngajinya.

Berdasarkan preseden sistem SKS di perguruan tinggi, sistem syarat kecakapan umum dan syarat kecakapan khusus dalam gerakan pramuka, dan sistem Iqro' model penerapan sistem SKK untuk pendidikan kesetaraan ini dikembangkan. Hal-hal yang diambil dari ketiga sistem tersebut adalah model pembobotan kompetensi menjadi satuan kredit kompetensi (skk), kalender pendidikan, cara mengadministrasikan ketuntasan belajar, dan cara pengujiannya.

\section{Jabaran skk}

Rincian satuan (unit-unit) skk pendidikan kesetaraan dimulai dengan menjabarkan atau merinci bobot Standar Kompetensi (SK) dan Kompetensi Dasar (KD) yang telah ditetapkan oleh standar isi untuk Program Paket A, Program Paket B, dan Program Paket C menjadi satuan-satuan skk. Sebagai ilustrasi untuk mata pelajaran Pendidikan Agama Islam pada Program Paket C pada Tingkatan V atau Derajat Mahir Dasar atau Setara Kelas X SMA atau MA memiliki bobot dua skk. Berdasarkan dokumen Permendiknas No. 14 Tahun 2007 pada bagian lampiran tiga, untuk Program Paket $\mathrm{C}$, pada tingkatan $\mathrm{V}$ tersebut mata pelajaran Pendidikan Agama Islam terdiri dari 12 SK dan 34 KD.

Berdasarkan bobot skk yang ditetapkan standar isi tersebut, yaitu sebesar 2 skk maka apabila setiap KD diberi bobot yang sama maka setiap KD memiliki unit skk sebesar 0,058 (dengan perhitungan: 2 skk dibagi $34 \mathrm{KD}=0,058$ ). Dengan perhitungan tersebut apabila seorang peserta didik telah mampu menunjukkan kompetensi nomor 4.1 dan 4.2 dan telah dinilai lulus uji kompetensi oleh tutor maka berarti telah memperoleh skk sebesar 0,058 dan 0,058.

Namun demikian, dengan mempertimbangkan tingkat kerumitan kompetensi, tingkat kesulitan, dan karakteristik daerah; pembagian dan penentuan bobot skk perlu dilakukan secara tidak pukul rata. Untuk KD yang memiliki kerumitan tinggi, sulit, serta bernilai penting dan relevansi tinggi dengan karakteristik dan kebutuhan daerah maka bobot skk-nya harus diberi lebih tinggi. Sebaliknya untuk KD yang tidak rumit, sederhana, dan tidak penting atau tidak relevan dengan kebutuhan daerah harus diberi bobot skk-nya lebih rendah. Hal tersebut untuk mengakomodasi variabilitas kekhasan karakteristik dan kebutuhan daerah sesuai dengan paradigma Kurikulum Tingkat Satuan Pendidikan (KTSP); untuk pendidikan kesetaraan 
pengembangan KTSP menjadi kewenangan pemerintah daerah provinsi dan kabupaten atau kota dalam menetapkannya. Hal kedua dan ketiga yang dilakukan adalah menyusun jabaran unit-unit SKK untuk setiap mata pelajaran dan menyusun buku catatan pencapaian catatan ketuntasan belajar. Jabaran SKK dikemas dalam bentuk tabel yang kolomnya terdiri dari nama kompetensi dan bobot sks-nya. Buku catatan rekaman ketuntasan belajar dikemas dalam bentuk "Buku Saku SKK Pendidikan Kesetaraan".

Contoh Format Jabaran SKK pada Mata Pelajaran Pendidikan Agama Islam

\section{Jabaran SKK Pendidikan Kesetaraan Program Paket C}

Tingkatan : V

Derajad : Mahir 1

Kesetaraan : Kelas X SMA atau MA

Bobor SKK : 2

\section{Keterangan:}

1. Pada tingkatan ini, mata pelajaran Pendidikan Agama memiliki bobot 2(dua) SKK yang terdiri atas 12 Standar Kompetensi (SK) dan 34 Kompetensi Dasar (KD).

2. Distribusi bobot SKK untuk masing-masing Kompetensi Dasar adalah sebagai berikut:

\begin{tabular}{|c|c|c|}
\hline No. & Standar Kompetensi dan Kompetensi Dasar & $\begin{array}{l}\text { Bobot } \\
\text { SKK }\end{array}$ \\
\hline 1. & $\begin{array}{l}\text { Memahami ayat-ayat Al-Qur'an tentang manusia } \\
\text { dan tugasnya sebagai khalifah di bumi: }\end{array}$ & \\
\hline & $\begin{array}{l}\text { 1.1 Membaca QS Al-Baqarah; 30, Al-Mukminun; } \\
\text { 12-14, Az-Zariyat; } 56 \text { dan An Nahl : } 78 \\
\text { 1.2 Menyebutkan arti QS Al-Baqarah; 30, Al- } \\
\text { Mukminun; 12-14, Az-Zariyat; } 56 \text { dan An Nahl : } \\
78 . \\
\text { 1.3 Menampilkan perilaku sebagai khalifah di bumi } \\
\text { seperti terkandung dalam QS Al-Baqarah;30, } \\
\text { Al-Mukminun; 12-14, Az-Zariyat; } 56 \text { dan An } \\
\text { Nahl : } 78 \text {. }\end{array}$ & $\begin{array}{l}0,058 \\
0,058 \\
0,058\end{array}$ \\
\hline 2. & $\ldots \ldots \ldots$ & \\
\hline 3. & Dan & \\
\hline
\end{tabular}

Berikut adalah contoh format pada buku saku SKK 
Contoh Format Buku Saku SKK Warga Belajar pada Mata Pelajaran Pendidikan Agama Islam

\section{SKK Pendidikan Kesetaraan Program Paket C}

$\begin{array}{ll}\text { Tingkatan } & : \text { V } \\ \text { Derajad } & : \text { Mahir } 1 \\ \text { Kesetaraan } & : \text { Kelas X SMA atau MA } \\ \text { Bobor SKK } & : 2\end{array}$

\section{Keterangan:}

1. Pada tingkatan Mahir 1 ini, mata pelajaran Pendidikan Agama memiliki bobot 2 (dua) SKK yang terdiri atas 12 Standar Kompetensi (SK) dan 34 Kompetensi Dasar (KD).

2. Kompetensi dasar ini diuraikan menjadi beberapa indikator, sebagaimana tertulis dalam buku jabaran ini.

3. Apabila warga belajar telah merasa mampu menguasai satu atau lebih kompetensi dengan mampu menampilkan indikator yang dituntut maka warga belajar mengajukan diri untuk menempuh uji kompetensi kepada tutor yang relevan.

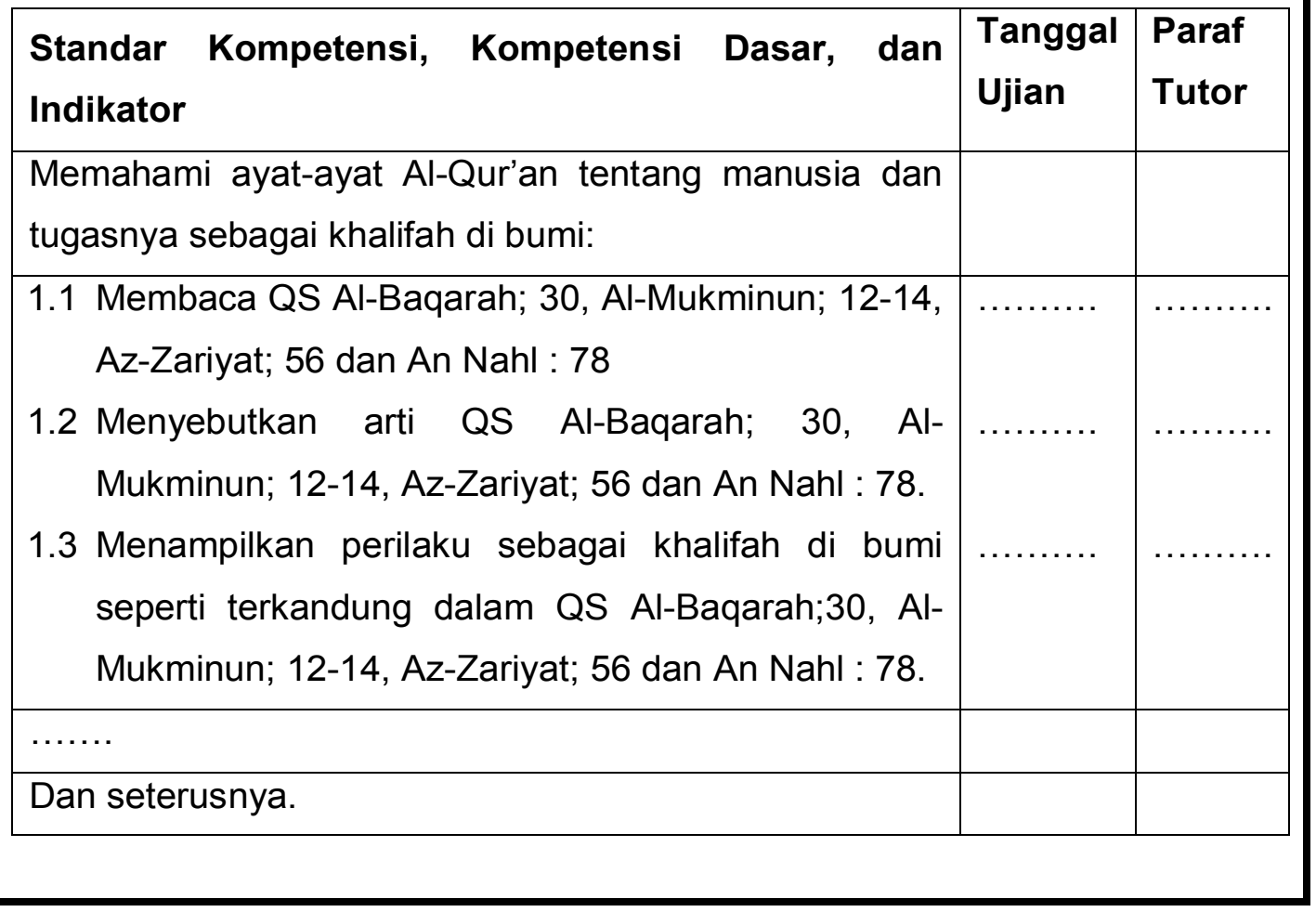

\section{Komponen Pendukung}

Jabaran SKK dan format buku catatan ketuntasan belajar dalam bentuk buku saku warga belajar hanya sebagian dari komponen sistem yang dikembangkan untuk implementasi sistem SKK dalam pendidikan kesetaraan. Berdasarkan keseluruhan konsep hipotetis ini masih ada beberapa komponen pokok maupun komponen pendukung yang harus disiapkan dan diujicobakan. Pada tahun pertama dan kedua (2006 dan 2007) telah berhasil dikembangkan satu prototipe model tentang cara mengembangkan satuan SKK beserta petunjuk pelaksanaannya. Selanjutnya pada tahun 2007 dikembangkan pedoman atau manual berupa acuan kerja warga belajar, acuan 
kerja tutor, dan acuan kerja penyelenggara. Di samping itu, berdasarkan eksplorasi lapangan untuk menerapkan pola SKK pada Program Pendidikan Kesetaraan dibutuhkan pula modul atau bahan belajar yang bersifat "doing by your self" atau modul belajar (mandiri) dan perangkat tes pengukuran keberhasilan belajar yang bersifat self asessment test. Komponen lain yang harus disiapkan pula adalah manual manajemen dan payung hukum (semacam Permendiknas) tentang implementasi sistem SKK sehingga menjadi kebijakan publik yang dapat diterapkan di lapangan.

Sistem SKK adalah sebuah sistem. Oleh karena itu, penerapannya di lapangan membutuhkan dukungan yang bersifat sistemik pula dari komponen-komponen yang membentuk sistem itu. Apa yang tengah dipikirkan dan dijabarkan dalam penelitian ini yang tengah dikerjakan di Jawa Timur oleh BPPNFI Regional IV Surabaya bekerja sama dengan Jurusan PLS Universitas Negeri Malang (UM) dengan judul proyek Pengelolaan Ketuntasan Belajar pada Pendidikan Kesetaraan dengan Model SKK hasilnya masih bersifat parsial. Agar implementasinya di lapangan benar-benar kafah (menyeluruh) membutuhkan dukungan berbagai komponen sistem lainnya, termasuk instrumental input pendidikan lain yang berupa korp tutor, alat dan media belajar, penyelenggara, birokrasi pendidikan, dan subsistem evaluasi hasil belajar. Tidak kalah pentingnya adalah terdapatnya kebijakan pemerintah dan peraturan-perundangan yang mampu memayungi secara hukum terhadap implementasi sistem SKK untuk Program Pendidikan Kesetaraan.

Sebagai sebuah tawaran baru yang akan membawa implikasi pada perubahan sisdiknas secara agak ekstrem maka wajar bila kemudian muncul pro dan kontra di tengah masyarakat terhadap sistem SKK. Terlepas dari adanya pro kontra terhadap penerapan sistem SKK tersebut, kiranya peluang perubahan positif yang dibuka Pemerintah tersebut perlu disambut positif dengan tetap memperhatikan kelemahan dan ancaman yang ada. Banyak pihak mengakui bila penerapan sistem SKS di sekolah dan perguruan tinggi sebagai sesuatu yang ideal dan sangat baik untuk membangun mutu pendidikan nasional.

SSK sebagaimana yang terjadi di Perguruan Tinggi (PT) pun baru bisa mantap setelah diterapkan selama lebih dari sepuluh tahun. Sistem SKS di Perguruan Tinggi dimulai dirintis pada tahun 1979 berdasarkan Keputusan Mendikbud RI No. 0124/ M1979. Kemudian sistem itu disempurnakan lagi pada tahun 1982 melalui SK Mendikbud No. 0211/M/1982. Pada masa itu pendapat pro kontra juga marak. Dan akhirnya terbukti, sistem SKS lebih diterima daripada sistem lama, yaitu sistem tingkat dan sistem gugur. Meskipun harus diakui bahwa ada beberapa PT yang menerapkan sistem SKS secara tidak penuh, misalnya dengan dikombinasikan dengan model paket, setengah paket, dan masih adanya sistem gugur.

Sebenarnya prototipe model SKS untuk tingkat sekolah dasar dan sekolah menengah pernah dikembangkan di Indonesia melalui Proyek Perintis Sekolah Pembangunan (PPSP) di berbagai kota di indonesia. Hanya saja, model yang diterapkan di sekolah PPSP tidak secara resmi diberi label sistem SKS atau pun SKK, melainkan disebut sebagai sistem modul. Pada akhirnya pada tahun 1980-an, sistem PPSP itu tidak dilanjutkan lagi karena dinilai mahal dari segi pembiayaan, terutama untuk mencetak modul dan lembar kerja siswa. Namun sesungguhnya, banyak pihak mengakui bahwa kemahalan biaya itu akan bisa dikompensasi bila sistem modul diterapkan secara massal.

Berdasarkan pengalaman-pengalaman itu, penerapan sistem SKK bukanlah sesuatu yang perlu dikhawatirkan. Justru sebaliknya perlu disambut sebagai sebuah peluang bagi perbaikan sisdiknas menuju terciptanya masyarakat belajar, masyarakat sadar belajar, dan masyarakat yang belajar dengan sadar. Ini adalah sebuah peluang emas besar bagi Program Pendidikan Kesetaraan untuk menjadi jalur utama atau arus utama bagi masyarakat untuk memperoleh layanan pendidikan dasar dan menengah tanpa terikat pada koridor ruang kelas, waktu, dan tempat.

Ada banyak manfaat langsung dan tidak langsung yang bisa dipetik dengan pola pengajaran sistem SKK yang mirip dan merupakan turunan (derivasi) sistem SKS ini. Salah satu manfaat langsung adalah terakomodasinya variasi kemampuan dan gaya belajar individu warga belajar. Warga belajar yang mampu dan punya sumber daya bisa menyelesaikan beban studi lebih cepat. Adapun warga belajar kurang berkemampuan dan kurang sumber daya belajar dapat menunda penyesaian studinya.

Pada sisi lain sistem SKK yang diterapkan secara murni bisa mengakomodasi pola multientry and multiexit. Artinya, warga belajar bisa atau boleh masuk ke program belajar pendidikan kesetaraan kapan saja dan keluar (dalam arti terminal) kapan saja, tidak perlu harus menunggu awal dan akhir tahun ajaran. Dengan pola multientry and multiexit itu, sistem SKK dapat pula mengakomodasi kasus cuti belajar yang disebabkan karena berbagai alasan sebagaimana terjadi pada cuti kuliah di perguruan tinggi. Misalnya, seorang warga 
belajar harus istirahat dari belajarnya karena kehabisan biaya maka ia harus bekerja dulu atau menunggu cukupnya biaya. Demikian juga warga belajar yang tengah melahirkan, sakit, dan mendapat pekerjaan maka ia bisa cuti belajar dulu. Suatu saat nanti, setelah urusan cuti tersebut selesai maka yang bersangkutan boleh melanjutkan lagi belajarnya sesuai dengan tingkat atau jumlah SKK yang masih harus diselesaikan.

Sistem SKS dapat pula bermanfaat bagi terciptanya pribadi subjek belajar yang mampu tampil sebagai pelajar secara swaarah (self directed learner). Pada tingkatan komunitas, subjek belajar swaarah akan bisa membentuk masyarakat belajar sesuai dengan prinsip pendidikan sepanjang hayat. Mengapa demikian? Karena sistem SKK membentuk pribadi subjek belajar yang mandiri. Subjek belajar yang mandiri akan terbiasa sadar tujuan belajar, mengetahui akses sumber belajar, mampu mengelola arah dan kecepatan belajar serta bisa mengukur keberhasilan belajar, dan mampu merencanakan program belajarnya sendiri.

Bila sistem SKK bisa diterapkan secara murni dan konsekuen, model ini dapat dimanfaatkan untuk mengubah dan hijrah budaya belajar dari perilaku belajar pasif menjadi perilaku belajar aktif, dari budaya belajar tak sadar tujuan menjadi insan belajar yang sadar tujuan, dan budaya belajar yang diarahkan menjadi budaya belajar dengan pengarahan oleh diri sendiri. Melalui pembiasaan, pengembangan gaya belajar, dan budaya belajar yang swaarah (self directed learning) sebagaimana yang dituntut sistem SKK akan lahir orang-orang yang pandai mengelola kebutuhan dan kegiatan belajarnya. Pada akhirnya akan lahir individu yang pintar dan cerdik merencanakan dan mengelola kegiatan belajarnya dan kehidupannya sendiri. Pada tingkat komunitas akan tercipta sebuah masyarakat yang belajar dengan berenergi internal bukan sebuah masyarakat yang belajar karena didorong dan dipaksa oleh pihak eksternal sebagaimana yang banyak terjadi sekarang ini.

Sistem SKK juga akan mampu mengakomodasi kebijakan, kebutuhan, dan keinginan akan pengakuan kemampuan atau kompetensi pengalaman belajar sebelumnya (recognition of prior learning) terdahulu. Dengan sistem SKK pengakuan terhadap pengalaman belajar sebelumnya dapat dilakukan melalui tes kompetensi atau tes alih kredit. Seorang warga belajar atau calon warga belajar pendidikan kesetaraan yang memiliki kemampuan yang didapat dari berbagai model belajar masyarakat yang isinya sama dengan atau kompetibel dengan isi pendidikan kesetaraan dapat mengajukan pengakuan SKK melalui tes untuk memperoleh penghargaan sejumlah SKK sebagaimana standar isi yang ditetapkan.

Dengan berbagai potensi keunggulannya tersebut, sistem SKK bisa menjadi pintu masuk bagi terciptanya individu subjek pelajar aktif dan terwujudnya masyarakat belajar (learning society) yang kita citacitakan dalam konsepsi prinsip belajar seumur hidup. Pewujudan itu bisa terjadi bila penerapan sistem SKK dikembangkan dan diterapkan dengan cara dan arah yang benar.

Direktorat Kesetaraan Ditjen PLS Depdiknas (2006) telah menerbitkan sebuah dokumen yang diberi judul Reformasi Pendidikan Kesetaraan yang salah satu isinya memaparkan adanya berbagai model layanan pembelajaran yang disediakan untuk pendidikan kesetaraan. Model layanan yang dikembangkan dalam pendidikan kesetaraan dilakukan melalui diversifikasi layanan yang disesuaikan dengan karaketeristik satuan pendidikan dan peserta didik. Diversifikasi layanan pendidikan ini disediakan untuk merespon disparitas, potensi, kebutuhan, dan kompetensi masyarakat yang majemuk. Beberapa model layanan yang dikembangkan di antaranya adalah komunitas home schooling, mobile learning, distance learning melalui e-learning, individual learning, kelompok belajar dan layanan khusus bagi daerah bencana. Berbagai pola alternatif layanan pendidikan kesetaraan yang relatif baru adalah komunitas e-learning, sekolahrumah (komunitas sekolahrumah), komunitas belajar mandiri, door to door education service, mobile class, dan layanan bagi siswa yang gagal ujian nasional (Directorate of Equivalency Education, Directorate General of Out of School Education, Ministery of National Education Indonesia, 2007).

Bahkan jauh sebelumnya, Supriyono (1995) melalui serangkaian kegiatan rintisan penyelenggaraan Program Paket B pernah mengusulkan adanya berbagai model alternatif penyelenggaraan Program Paket B, yaitu model intensif, crash program, model klasikal dan reguler, model cicilan, pembelajaran kelompok, serta belajar mandiri. Berbagai model belajar tersebut membutuhkan sebuah sistem penataan usaha atau 
pengelolaan ketuntasan belajar yang mampu menghubungkannya menuju sistem akreditasi dan sertifikasi yang mampu menjamin standar mutu dan rasa keadilan.

Untuk meminimalisir penyelewengan sertifikat program paket itu Depdiknas telah mengetatkan prosedur ujian penyetaraan sebagaimana publikasi on line Dit Penmas (http://www.dikmas.depdiknas.go.id/ go.php?a=1\&to=f24). Mekanisme ujian akhir program penyetaraan paket $C$ (setara SMA) dilaksanakan secara ketat dan hasilnya didata di tingkat pusat. Oleh sebab itu, bila ada pihak yang meragukan keasliannya, ijazah Program Paket $C$ dapat diverifikasi di Pusat Penilaian Pendidikan (Puspendik) Depdiknas.

Beberapa potensi kelemahan dan ancaman penerapan sistem SKK pada Program Pendidikan Kesetaraan bersumber dari tutor, warga belajar, dan budaya masyarakat. Para tutor pendidikan kesetaraan belum mampu berperan diri sebagai fasilitator belajar untuk sistem SKS karena kebiasaan mengajar mereka yang cenderung menggurui, memberitahukan atau menceritakan isi buku (telling text books), dan kekurangan prasarana dan sarana belajar internal penyelenggara pendidikan kesetaraan terutama bahan pustaka, laboratorium, dan bengkel atau studio.

Di samping menuntut kesiapan saranaprasarana, korps tutor, dan kapasitas manajemen penyelenggara yang cukup dan yang kompetibel dengan model sistem SKK juga dituntut adanya perubahan gaya, kebiasaan bahkan budaya belajar pada diri peserta didik. Tanpa melakukan penelitian pun, sudah bisa ditarik kesimpulan bahwa kebiasaan belajar para murid-murid sekolah dan warga belajar di pendidikan nonformal sekarang ini adalah cenderung dependent (bergantung) kepada pendidik. Selama ini para murid sekolah dan warga belajar pendidikan nonformal sudah terbiasa belajar dengan cara mekanis dengan mengikuti instruksi, perintah, dan penugasan pihak guru atau tutor. Murid-murid dan warga belajar menjadi kurang kreatif dalam mencari sendiri ilmu pengetahuan yang dibutuhkan.

Mengapa terjadi hal yang demikian? Salah satu sebabnya adalah kurang atau belum tumbuhnya kesadaran para peserta didik tentang tujuan dan manfaat belajar itu bagi diri sendiri dan kehidupan sekarang dan masa depan. Dengan kata lain, para murid sekolah belum mampu berdiri sebagai subjek belajar yang sadar tujuan. Bagi para murid sekolah, belajar masih dipandang sebagai kewajiban dan beban dibanding sebagai kebutuhan mereka sendiri dalam merajut masa kini dan masa depan. Demikian pula yang terjadi pada Program Pendidikan Kesetaraan.

Salah satu prasyarat agar sistem SKK berjalan efektif dan dapat berjalan secara otomatis adalah terwujudnya subjek belajar yang sadar kebutuhan belajar, mengetahui sumber daya belajar yang bisa diakses dan dimanfaatkan, mampu mengarahkan sendiri aktivitas, arah, dan kecepatan belajar mereka sendiri, serta mampu mengukur tingkat keberhasilan belajar mereka untuk merencanakan lebih lanjut program belajar berikutnya. Dalam hal ini subjek belajar harus berdiri sebagai organisme belajar yang berenergi internal untuk belajar, sadar tujuan, mengetahui ukuran kemampuan, dan mengatur proses belajarnya sendiri; bukan organisme yang diatur oleh pihak lain.

Kelemahan-kelemahan itu harus sudah diantisipasi oleh pihak-pihak yang berkepentingan. Penerapan sistem SKK harus dilakukan secara bertahap, dimulai pada satuan-satuan penyelenggara binaan lembaga pengembangan pendidikan nonformal seperti perguruan tinggi dan badan penelitian pendidikan lainnya. Secara simultan perlu dilakukan upaya melengkapi prasana, sarana, dan prasyarat instrumental input yang dibutuhkan. Termasuk dalam hal ini adalah penyelenggaraan pelatihan, lokakarya, dan pendampingan dalam rangka peningkatan kapasitas (capacity building) manajemen organisasi (satuan penyelenggara pendidikan kesetaraan) dan para tutor agar mampu mengelola dan memfasilitasi pembelajaran dengan sistem SKK. Penerapan sistem SKK masih juga akan membutuhkan kombinasi dengan sistem klasikal, artinya masih ada sistem kenaikan kelas atau darjah.

\section{KESIMPULAN}

Dengan menerapkan sistem SKK sebagai arus utama penyelenggaraan pendididkan kesetaraan maka berbagai potensi keluasan dan keunggulan pendidikan nonformal akan mudah untuk diimplementasikan. Beberapa model layanan pendidikan kesetaraan, seperti homeschooling community, mobile learning unit, distance learning melalui e-learning, individual learning, kelompok belajar dan layanan khusus bagi daerah bencana, daerah terasing, komunitas nomaden (berpindah tempat), dan layanan belajar intensif dapat dipertemukan dalam sebuah sistem yang interkoneksi, yakni SKK dan UNPK.

Masih dibutuhkan berbagai komponen sistem dan pengaturan agar sistem SKK benar-benar mampu 
efektif mengakomodasi berbagai keinginan, kebutuhan, dan potensi keluwesan-keunggulan tersebut. Temuan penelitian ini, yang berupa model jabaran SKK dan model penatausahaan ketuntasan belajar serta potensi temuan penelitian terkait membutuhkan dukungan kebijakan pemangku regulasi pendidikan nasional dan daerah. Penelitian lanjutan masih dilaksanakan oleh
BPPLSP Reginal IV Surabaya bekerja sama dengan tim peneliti dari Jurusan PLS UM. Lebih lanjut, peran berbagai pihak, termasuk balai pengembangan pendidikan nonformal perlu difasilitasi secara padu oleh Direktorat Pendidikan Kesetaraan Depdiknas sebagai pemangku kebijakan nasional di bidang pendidikan kesetaraan.

\section{DAFTAR PUSTAKA}

Directorate of Equivalency Education, Directorate General of Out of School Education, Ministery of National Education Indonesia. (2007). Profile and Prospect of equivalency education. Jakarta.

Direktorat Pendidikan Kesetaraan, Ditjen PLSP Depdiknas. (2006). Reformasi pendidikan kesetaraan. Jakarta: Pendidikan Kesetaraan, Ditjen PLSP Depdiknas.

Direktorat Pendidikan Kesetaraan, Ditjen PNFi Depdiknas. (2007). Komunitas sekolah rumah sebagai satuan pendidikan kesetaraan. Jakarta: Pendidikan Kesetaraan, Ditjen PLSP Depdiknas.

Direktorat Jenderal PLSP. (2003). Rencana strategis Ditjen PLSP. (http://www.dikmas.depdiknas.go.id/go.php?a=1\&to=f24, diakses pada tanggal 01/03/04)

Konsorsium IImu Pendidikan, Direktorat Jenderal Pendidikan Tinggi, Departemen Pendidikan dan Kebudayaan. (1980). Pedoman pelaksanaan pola pembaharuan sistem pendidikan tenaga kependidikan di Indonesia, buku II tentang kurikulum inti pendidikan tenaga kependidikan program S1. Jakarta: Depdikbud.

Supriyono. (1995). Menyiasati Kelangkaan Sumber Daya Dalam Penyelenggaraan Kejar Paket B.
LPM IKIP Malang: Jurnal Abdi Masyarakat, 12 (1), 133-150.

Universitas Negeri Malang. (2007). Pedoman pendidikan universitas negeri malang. Malang: Universitas Negeri Malang.

Yulaelawati, E. (2005). Pendidikan kesetaraan: Perluasan akses dan peningkatan mutu. Hand Out disampaikan pada Pelatihan Pengelola Program Pendidikan Kesetaraan 21 September 2005. Yogyakarta.

(2002) Surat Edaran Direktur Jenderal Pendidikan Dasar dan Menengah Departemen Pendidikan Nasional No. 3633/C/MN/2002 Tanggal 27 Mei 2002 Tentang Penghapusan Program Ujian Persamaan (UPERS).

(2003) Undang-Undang No. 20 Tahun 2003 Tentang Sistem Pendidikan Nasional.

(2003) Keputusan Mendiknas No. 086/U/2003 Tentang Penghapusan Ujian Persamaan.

(2004) Keputusan Mendiknas No. 132/U/2004 Tentang Program Paket C.

(2005) Peraturan Pemerintah No. 19 Tahun 2005 Tentang Standar Nasional Pendidikan.

(2007) Peraturan Menteri Pendidikan Nasional (Permendiknas) No. 14 Tahun 2007 Tentang Standar Isi Pendidikan Kesetaraan Program Paket A, B, dan C. 